\title{
Multilevel Analysis: The Effect of Socioeconomic, Birth Weight, and Nutrition Intake with Wasting in Boyolali, Central Java
}

\author{
Nur Fika Roobiati'), Eti Poncorini²), Bhisma Murti3) \\ 1)Masters Program in Public Health, Universitas Sebelas Maret \\ ${ }^{2)}$ Faculty of Medicine, Universitas Sebelas Maret
}

\begin{abstract}
Background: Wasting is a major health problem. Globally, wasting accounts for $4.7 \%$ of all deaths of children aged under 5 years. Severely wasted children are, on average, 11 times more likely to die than their healthy counterparts. This study aimed to investigate the effect of socioeconomic, birth weight, and nutrition intake with wasting in Boyolali, Central Java, using multilevel analysis.

Subjects and Method: This was an analytic observational study with a case control design. The study was conducted in Boyolali, Central Java, from April to May 2018. Twenty five posyandus (integrated health posts) were selected and positioned at level 2 in the multilevel model (MLM) analysis. A sample of 200 children under five was selected for this study by fixed disease sampling and positioned at level 1 in the MLM. The dependent variable was wasting. The independent variables were birth weight, nutrition intake, maternal education, family income, and family size. Data on wasting was measured by microtoise and weight scale. Nutrition intake was measured by food recall. The other variables were collected by questionnaire. Data were analyzed by a MLM analysis.

Results: The risk of wasting decreased with high family income $(b=-1.92 ; 95 \% \mathrm{CI}=-3.77$ to -0.08 ; $\mathrm{p}=0.041)$, high maternal education $(\mathrm{b}=-2.68 ; 95 \% \mathrm{CI}=-4.97$ to $-0.38 ; \mathrm{p}=0.022)$, small family size $(b=-2.01 ; 95 \% C I=-3.67$ to $-0.35 ; p=0.018)$, normal birth weight $(b=-2.55 ; 95 \% \mathrm{CI}=-4.89$ to $0.21 ; \mathrm{p}=0.033)$, good nutritional intake $(\mathrm{b}=-2.18 ; 95 \% \mathrm{CI}=-3.95$ to $-0.41 ; \mathrm{p}=0.016)$. Posyandu had a contextual effect on wasting with ICC $=21.45 \%$.

Conclusion: The risk of wasting decreases with high family income, high maternal education, small family size, normal birth weight, good nutritional intake. Posyandu has a contextual effect on wasting.
\end{abstract}

Keywords: wasting, socioeconomic, birth weight, nutrition intake, children under five

\section{Correspondence:}

Nur Fika Roobiati. Masters Program in Public Health, Universitas Sebelas Maret, Jl. Ir. Sutami No. 36 A, Surakarta 57126, Central Java. Email: nur_fika@ymail.com. Mobile: +6285799504324.

\section{BACKGROUND}

In children's life, there is a phase of growth and development. Children's growth and development are strongly influenced by adequate nutrition. If the child's nutritional needs do not meet, the child will experience nutritional disorders. As a result, the child becomes susceptible to illness, passivity, fatigue, lethargy, drowsiness, unable to receive lessons properly, which causes lack of achievement (Ministry of Health, 2014).
Malnutrition in infants is one of the health problems that can have an impact on death (Roba et al., 2016; Central Java Health Office, 2015; Fentahun et al., 2016).

The prevalence of wasting problems in Indonesia in 2013 was $12.1 \%$ (Balitbangkes, 2013). Based on reports from districts or cities, the number of cases of wasting (WHZ) in Central Java in 2015 was 922 cases (Central Java Health Office, 2015). Meanwhile, the case of wasting in Boyolali Regency in 2017 was $7.14 \%$ 
(Boyolali Health Office, 2017). The high prevalence of undernourished and malnourished children under five is influenced by three main factors, namely the poor quality of the quantity of food consumption as a result of the low family food security, poor parenting and low access to health facilities (Hendrayati et al., 2013).

Factors related to wasting include family socioeconomic status, parental education, nutritional status, birth weight, childhood illness, water supply, health care, ethnicity (Mgongo et al., 2017; Fentahun et al., 2016; Kavosi et al., 2014; Abubakar et al., 2012; Yisak et al., 2015; Asfaw et al., 2015; Oliveira et al., 2014; Fekadu et al., 2015). Other factors that cause wasting are lack of nutrient intake and the occurrence of diarrhea in infants (Roba et al., 2016; Darsene et al., 2017; Asfaw et al., 2015; Fekadu et al., 2015). The importance of nutritional intake in toddlers prevents the occurrence of chronic diseases (Rios et al., 2017). Infants who are not given breast milk (ASI) are more susceptible to wasting than infants who are given breast milk (Fekadu et al., 2015).

Wasting on children under five can reduce intelligence, productivity, creativity, and greatly affect the quality of human resources (Hendrayati et al., 2013). Wasting in infants can make growth stunted (Manullang et al., 2012). In the long run, the child will experience cognitive impairment, decreased learning achievement, behavioral disorders, and even increased risk of death. The impact will be detrimental to the nation and can cause lost generation if it is experienced by many children without response to the disease. The child will have less productivity and it can increase morbidity and mortality in Indonesia in the future (Pramudya et al., 2012). Based on the description above, researchers are interested in conducting research entitled "the influence of family socio economic factors, birth weight, and nutritional intake of wasting.

\section{SUBJECTS AND METHOD \\ 1. Study Design \\ This was an analytic observational study with a case control design. The study was conducted in 25 posyandus (integrated health posts) in Boyolali, Central Java, from April to May 2018.}

\section{Population and Samples}

The source population in this study was infant aged 12-60 Boyolali posyandu in April to May 2018. A sample of 200 infants was selected by fixed disease sampling.

\section{Study Variables}

The dependent variable was wasting. The independent variables were family income, maternal education, number of family members, birth weight, and nutritional intake at level 1. Posyandu was at level 2.

\section{Operational Definition of Variables}

Maternal education was defined as a structured and tiered formal education consisting of primary, secondary, and tertiary education. The data were collected by questionnaire. The measurement scale was categorical, coded o for <senior high school and 1 for $\geq$ senior high school.

Parents' income was defined as the real income amount of all household members used to meet the needs of both the joint and the individual in the household.

The number of family members is the total number of people in the family. Birth weight is the weight of a baby weighing within the first hour after birth (gram). Nutritional intake is a nutrient consumed by the body for doing the activity and to achieve optimal health. Posyandu is the type or level of posyandu present in the community. 
Wasting is a failure to achieve optimal growth, measured by weight / body height (weight for height). Measured with an infantometer or length board to measure the length of a child's body aged 6-24 months, and microtoise to measure the height of children under five years of age 25-59 months.

\section{Research Instruments}

The data collection techniques were conducted with primary data and secondary data. The primary data were obtained using questionnaires distributed to the subjects. The secondary data were obtained from Boyolali District Health Office in the form of toddlers' data in Boyolali District. The instruments used were the pre-screening development questionnaire (KPSP), food recall, microtoise, infantometer, and scales to measure height / height and weigh toddler weight.

\section{Data Analysis}

Univariate analysis was conducted to see the frequency distribution and characteristics of research subjects, while bivariate analysis was done using chi-square test and odds ratio (OR) with 95\% confidence level (CI) to study the relationship between wasting incidence with independent variables. Multivariate analysis employed multilevel logistic regression.

\section{Research Ethics}

The research ethics include informed consent, anonymity, confidentiality and ethical clearance. The ethical clearance in this study was conducted at Dr. Moewardi hospital, Surakarta and was declared as worthy of ethics based on decision letter number: 410 / IV / HREC / 2018.

\section{RESULTS}

\section{Study Subject Characteristics}

Study subjects in this study consisted of 200 children under five, consisting of 50 wasted children and 150 children with normal weight. The frequency distribution of the study subjects characteristics is described in Table 1.

Table 1. Study Subject Characteristics

\begin{tabular}{lcc}
\hline Characteristics & n & \% \\
\hline Children Age & & \\
12-36 months & 138 & 69.0 \\
37-6o months & 62 & 31.0 \\
Gender & & \\
Male & 98 & 49.0 \\
Female & 102 & 51.0 \\
\hline
\end{tabular}

Table 1 shows that most of the study subjects were female, amounting to 102 subjects (51.0\%), and most of them consisted of children aged 12-36 months totaling 138 subjects (69.0\%).

\section{Univariate Analysis}

Univariate analysis in this study include family income, maternal education, number of family members, birth weight, and nutritional intake that can be seen in Table 2.

Table 2. Univariate Analysis

\begin{tabular}{|c|c|c|}
\hline Variable & $\mathbf{N}$ & $\%$ \\
\hline \multicolumn{3}{|l|}{ Family Income } \\
\hline$<\operatorname{Rp} 1,651,650$ & 60 & 30.0 \\
\hline$\geq \operatorname{Rp} 1,651,650$ & 140 & 70.0 \\
\hline \multicolumn{3}{|l|}{ Maternal Education } \\
\hline No formal education & 1 & 0.5 \\
\hline Primary sschool & 28 & 14.0 \\
\hline Junior high school & 33 & 16.5 \\
\hline Senior high school & 123 & 61.5 \\
\hline Diploma & 7 & 3.5 \\
\hline Bachelor degree & 8 & 4.0 \\
\hline \multicolumn{3}{|l|}{ Family size } \\
\hline$\leq 4$ & 69 & 34.5 \\
\hline \multirow{2}{*}{\multicolumn{3}{|c|}{ Birth Weight }} \\
\hline & & \\
\hline$<2500$ & 35 & 17.5 \\
\hline$\geq 2500$ & 165 & 82.5 \\
\hline \multicolumn{3}{|l|}{ Nutritional Intake } \\
\hline < NAR (70\%) & 49 & 24.5 \\
\hline$\geq \operatorname{NAR}(70 \%)$ & 151 & 75.5 \\
\hline
\end{tabular}

Table 2 shows that study subjects with family income $\geq$ minimum regional wage (Rp 1,651,650) was 140 (70.0\%). Most of maternal education senior high school was 123 (61.5\%). Chidlren with family size $>4$ 
was 131 subjects (65.5\%). Most of children was born with normal birth weight ( $>2500$ ) (82.5\%). Most of the wasted children received nutritional intake <NAR (39, 79.6\%).

\section{Bivariate analysis}

Bivariate analysis was conducted to see the relationship of family income, maternal

Table 3. Chi-square test on the relationship between family income, maternal education, family size, birth weight, nutrition intake, and wasting

\begin{tabular}{|c|c|c|c|c|c|c|c|c|}
\hline \multirow{3}{*}{ Independent Variable } & \multicolumn{4}{|c|}{ Wasting } & \multirow{3}{*}{$\mathbf{O R}$} & \multicolumn{2}{|c|}{$95 \% \mathrm{CI}$} & \multirow{3}{*}{$\mathbf{p}$} \\
\hline & \multicolumn{2}{|c|}{ Yes } & \multicolumn{2}{|c|}{ No } & & \multirow{2}{*}{$\begin{array}{c}\text { Lower } \\
\text { Limit }\end{array}$} & \multirow{2}{*}{$\begin{array}{l}\text { Upper } \\
\text { Limit }\end{array}$} & \\
\hline & $\mathbf{n}$ & $\%$ & $\mathbf{n}$ & $\%$ & & & & \\
\hline \multicolumn{9}{|l|}{ Family income } \\
\hline$<$ Low income $(\operatorname{Rp} 1,651,650)$ & 42 & 70.0 & 18 & 30.0 & 0.026 & 0.011 & 0.064 & $<0.001$ \\
\hline$\geq$ High income(Rp 1,651,650) & 132 & 94.3 & 8 & $5 \cdot 7$ & & & & \\
\hline \multicolumn{9}{|l|}{ Maternal education } \\
\hline$\geq$ senior high school & 3 & 2.2 & 135 & 97.8 & 0.007 & 0.002 & 0.026 & $<0.001$ \\
\hline \multirow{2}{*}{\multicolumn{9}{|c|}{ Family size }} \\
\hline & & & & & & & & \\
\hline$\leq 4$ & 11 & 8.4 & 120 & 91.6 & 0.071 & 0.032 & 0.154 & $<0.001$ \\
\hline$>4$ & 39 & 56.5 & 30 & $43 \cdot 5$ & & & & \\
\hline \multicolumn{9}{|l|}{ Birth Weight } \\
\hline Low $(<2500 \mathrm{~g})$ & 31 & 88.6 & 4 & 11.4 & 0.017 & 0.005 & 0.053 & $<0.000$ \\
\hline Normal ( $\geq 2500 \mathrm{~g})$ & 19 & 11.5 & 146 & 88.5 & & & & \\
\hline \multicolumn{9}{|l|}{ Nutritional intake } \\
\hline < NAR (70\%) & 39 & 79.6 & 10 & 20.4 & 0.020 & 0.008 & 0.051 & $<0.001$ \\
\hline$\geq \operatorname{NAR}(70 \%)$ & 11 & $7 \cdot 3$ & 140 & 92.7 & & & & \\
\hline
\end{tabular}

\section{Multivariate Analysis}

Table 4 showed that the risk of wasting reduced with high family income $(b=-1.92$; $95 \% \mathrm{CI}=-3.77$ to $-0.08 ; \mathrm{p}<0.041)$, maternal education $\geq$ senior high school $(b=-2.68$; 95\% $\mathrm{CI}=-4.97$ to $-0.38 ; \mathrm{p}<0.022)$, large family size $(\mathrm{b}=-2.01 ; 95 \% \mathrm{CI}=-3.67$ to 0.35; $\mathrm{p}<0.018)$, normal birth weight $(\mathrm{b}=-$ $2.55 ; 95 \% \mathrm{CI}=-4.89$ to $-0.21 ; \mathrm{p}<0.033)$,

Table 4. The results of multilevel analysis on the determinants of wasting education, family size, birth weight, nutritional intake, and wasting. The result of bivariate analysis can be seen in Table 3 . Table 3 shows that family income, maternal education, number of family members, birth weight, and nutritional intake are statistically significant effect on the incidence of wasting. 


\section{DISCUSSIONS \\ 1. The effect of family income on the incidence of wasting}

The result of this study showed that there was an association between family income and the incidence of wasting. High family income reduced the risk of wasting 1.92 times compared to low family income.

The result of this study was supported by Kavosi et al. (2014), stated that children with growth disorder came from lowincome or poor family. Poverty was closely related to the unavailability of food, poor sanitation, and hygiene which also has an impact on the increased risk of infection and malnutrition in children. According to Oliveira et al., (2014), family with middle and low economic status was more likely to consume food with low nutrition, and it lead to the incidence of wasting. Poverty increased the incidence of wasting by 1.92 times.

According to Kumari et al., (2017), low income affected the amount of food consumed by the family both the quality and the quantity of food. It also increased the likelihood of getting the disease so that it could cause wasting. Families with high income allowed the mothers to provide nutritious foods for children so that their nutritional status tends to be good.

\section{The effect of maternal education on the incidence of wasting}

The result of this study showed that there was an association between maternal education and the incidence of wasting. Children from highly-educated mothers ( $\geq$ high school) decreased the risk of wasting by 2.68 times compared to children from loweducated mothers ( $<$ high school).

Maternal education was one of the factors that affected child growth disorders such as wasting. The proportion of wasting increased with the low level of parental formal education. Mothers with good education have the opportunity to have good occupation that could increase family income. In addition, mother would has better knowledge about health, good parenting, and would use health services to improve their children's health (Kavosi et al., 2014; Oliveira et al., 2014; Pei et al., 2014). Low-educated mothers increased the incidence of wasting by 2.68 times, which mean that children with low-educated mother was 2.68 times more likely to experience wasting compared to chilcren with highly-educated mothers.

The higher the education, the easier they would receive the information. Otherwise, if someone has a low level of education, it would inhibit the development of the person's attitude towards the acceptance of information and newly introduced values (Abubakar et al., 2012)

\section{The effect of family size on the incidence of wasting}

The result of this study showed that there was a $\mathrm{n}$ association between family size and the incidence of wasting. Children who came from family size $\leq 4$ decreased the risk of wasting by 2.01 times compared to children who came from large family size $>4$.

The result of this study was in line with a study by Asfaw et al. (2015) and Kavosi et al. (2014), which stated that children from family members $>4$ tend to get lack of parental attention and care. The number of members in the family would affect the parenting because the time and attention of the mothers to the child became divided which resulting in lack of attention and love received by the child, especially if the age gap between the children was too close. Therefore, the parents cannot monitor or pay attention to the growth of their children which would eventually affect the nutritional status of the children. Toddlers with the number of 
family members $>4$ could increase the incidence of wasting by 2.01 times, which mean that children from large family size $>4$ were 2.01 times more likely to experience wasting compared to children with $\leq 4$ family members.

Families with 5 - 6 members have lack of proportion of food sufficiency compared to families with less than 4 members. Therefore, the size of the family has an effect on food consumption, starvation in large families was more likely to happen than in small families (Labada et al., 2016).

\section{The effect of birth weight on the incidence of wasting}

The result of this study showed that birth weight was associated with the incidence of wasting. Birth weight $\geq 2500$ g decreased the risk of wasting by 2.55 times compared to children with birth weight $<2500 \mathrm{~g}$.

This study was in line with a study by Fekadu et al. (2015), which stated that infants with low birth weight were more likely to experience wasting compared to infants with normal birth weight.

Low birth weight also has long-term effects that were bad for health such as neonatal death, morbidity, decreased cognitive development, and chronic diseases. Babies with low birth weight increase the risk of death by 20 times than infants with normal birth weight (WHO, 2013).

\section{The effect of nutritional intake on the incidence of wasting}

The result of this study showed that there of nutritional intake affected the incidence of wasting. Low-birth weight infants increased the risk of death by 20 times compared to babies with normal birth weight. Toddlers who have nutritional intake $\geq$ number of needs $(70 \%)$ reduced the risk of wasting by 2.18 times compared to toddlers who have nutritional intake $<$ NAR $(70 \%)$.

The result of this study was in line with a study by Asfaw et al. (2015), which stated that nutritional intake greatly affected children growth. Nutritional intake affected the children nutritional status that could improve children intelligence. Children with lack of nutrition lowered their intelligence level. Malnutrition in children could lead to physical growth disorder and the child's brain was not optimal. Low nutritional intake could increase the incidence of wasting by 2.18 times, which mean that toddlers with low nutritional intake were 2.18 times more likely to experience wasting compared to toddlers with adequate nutritional intake.

Nutritional intake was a nutrient consumed by the body to move and achieve optimal health. Wasting in toddlers could hamper the growth. If wasting was not handled properly, it would develop into malnutrition, and serious malnutrition could cause death in children (Fentahun et al., 2016; Manullang et al., 2012)

\section{The effect of posyandu levels on the incidence of wasting}

The result of this study showed that there was a contextual effect of Posyandu level on the variation of wasting incidents (ICC= $21.45 \%$ ). Variations in the incidence of wasting were $21.45 \%$ affected by posyandu. Table 4 showed that the ICC score in this study was greater than the rule of thumb of $8-10 \%$, so the contextual effect in this study was Posyandu and it was very important to be noted.

Posyandu was one of the media to monitor the growth of children every month. The monitoring used Growth Chart (GC) to record weight growth based on age. Posyandu was one of the facilities that can be used to detect and monitor the incidence of wasting in early stage. Based on the descriptions above, maximizing the use of posyandu, improving the quality of posyandu services, and providing quality human resources were some of the influent- 
ial efforts for wasting prevention and handling (Ministry of Health RI, 2012).

Based on the results of this study, it can be concluded that there was a significant effect between family income, maternal education, family size, birth weight, and nutritional intake on wasting. Variations at the Posyandu level indicated that there was a contextual effect on the incidence of wasting.

\section{REFERENCES}

Abubakar A, Uriyo J, Msuya SE, Swai Mark, Stray-Pedersen B (2012). Prevalence and Risk Factors for Poor Nutritional Status among Children in The Kilimanjaro Region of Tanzania. International Journal of Environmental Research and Public Health, 9: 3506-3518. https://doi.org/10.3390/ijerph9103506

Asfaw M, Wondaferash M, Taha M, Dube L (2015). Prefalence of Undernutrition and Associated Factors among Children Aged between Six to Fifty Nine Months in Bule Hora District, South Ethiopia. BioMed Central Public Health, 15(41). https://doi.org/10.1186/s12889-015-1370-9.

Badan Penelitian dan Pengembangan Kesehatan (2013). Riset Kesehatan Dasar Tahun 2013. Jakarta: Depkes RI.

Darsene H, Geleto A, Gebeyehu A, Meseret $S$ (2017). Magnitude and Predictors of Undernutrition Among Children Aged Six To Fifty Nine Months in Ethiopia: A Cross Sectional Study. BioMed Central Public Health, 75(29). https://www.ncbi.nlm.nih.gov/pmc/articles/PMC5502324/pdf/13690_2017_Artic le_198.pdf

Dinas Kesehatan Jawa Tengah (2015). Profil Kesehatan Provinsi Jawa Tengah Tahun 2015. Semarang: Dinkes Jateng.
Fekadu Y, Mesfin A, Haile D, Stoecker BJ (2015). Factors Associated with Nutritional Status of Infants and Young Children in Somali Region, Ethiopia: A Cross- Sectional Study. BioMed Central Public Health, 15 (846). https://doi.org/10.1186/s12889-015-2190-7

Fentahun W, Wubshet M, Tariku A (2016). Undernutrition and Associated Factors Among Children Aged 6-59 Months in East Belesa District, Northwest Ethiopia: A Community Based Cross-Sectional Study. BioMed Central Public Health, 16(506). http://dx.doi.org/10.1186/s12889-o16-3180-o.

Hendrayati, Amir A, Darmawati (2013). Faktor yang Mempengaruhi Kejadian Wasting pada Anak Balita di Kecamatan Marioriwawo Kabupaten Soppeng. Media Gizi Pangan, 15. https://anzdoc.com/faktor-yang-mempengaruhi-kejadian-wasting-pada-anakbalita-d.html

Kavosi E, Rostami ZH, Kavosi Z, Nasihatkon A, Moghadami M and Heidari M. 2014. Prevalence and Determinants of Under-Nutrition among Children Under Six: A Cross-Sectional Survey in Fars Province, Iran. International Journal of Health Policy and Management, 3(2): 71-76.

Kementerian Kesehatan Republik Indonesia (2014). Peraturan Menteri Kesehatan Republik Indonesia Nomor 66 Tahun 2014 tentang Pemantauan Pertumbuhan, Perkembangan, dan Gangguan Tumbuh Kembang Anak. Jakarta: Kemenkes RI.

Labada A, Ismanto AY, Kundre R (2016). Hubungan Karakteristik Ibu dengan Status Gizi Balita yang Berkunjung di Puskesmas Bahu Manado. eJournal Keperawatan, 4(1). https://ejournal.- 
unsrat.ac.id/index.php/jkp/article/vi ew/11899/11488.

Manullang, Mona SJ (2012). Gambaran Pola Konsumsi dan Status Gizi Baduta (Bayi 6-24 Bulan) yang Telah Mendapatkan Makanan Tambahan Taburia di Kelurahan Kemenangan Tani Kecamatan Medan Tuntungan Tahun 2012. https://jurnal.usu.ac.id/index.php/gkre/article/view/5162

Mgongo M, Chotta NAS, Hashim TH, Uriyo JG, Damian DJ, Stray-Pedersen B, Msuya SE, Wandel M, Vangen S (2017). Underweight, Stunting and Wasting Among Children in Kilimanjaro Region, Tanzania; A Population-Based Cross-Sectional Study. International Journal of Environmental Research and Public Health, 14(509). https://www.ncbi.nlm.nih.gov/pmc/articles/PMC5451960/

Kumari V, Singh A (2017). Assessment of Nutritional Status of Pre-School Children of Anganwadi of Labour Colony, H.A.U. International Journal of Science Environment, 6(1). http://www.ijset.net/journal/1581.pdf

Oliveira FMDA, Correia LL, Silva AC, Campos JS, Machado MMT, Lindsay AC, Leite AJM, Rocha HAL, Cunha AJLA (2014). Prevalence and Determinants of Child Undernutrition and Stunting in Semiarid Region of Brazil. Rev Saude Publica, 48(1): 19-28. https://www.ncbi.nlm.nih.gov/pmc/articles/PMC4206126/

Pei L, Ren L, Yan H (2014). A Survey of Undernutrition in Children Under Three Years of Age in Rural Western China. BioMed Central Public Health, vol. 13.

Pramudya AE, Bardosono S (2012). Prevalensi Anak Beresiko Wasting dan Faktor-Faktor yang Berhubungan: Studi Cross Sectional Pada Anak Usia 3-9 Tahun di Pesantren Tapak Sunan Tahun 2011. vol. 2. http://lib.ui.ac.id/naskahringkas/2016-06/S-PDFAbdulla\%2oEmir\%2oPramudya

Rios EM, Sinigaglia O, Diaz B, Campos M and Palacios C. 2016. Development of A Diet Quality Score for Infants and Toddlers and Its Association with Weight. Journal Nutrit Health Food Science, 4(4). https://www.ncbi.nlm.nih.gov/pmc/articles/PMC5283385/

Roba KT, O'Connor TP, Belachew T, O'Brien NM (2016). Variations between Post- and Pre-Harvest Seasons in Stunting, Wasting, and Infant and Young Child Feeding (IYCF) Practices among Children 6-23 Months of Age in Lowland and Midland Agro-Ecological Zones of Rural Ethiopia. Pan African Medical Journal, 24(163). https://www.ncbi.nlm.nih.gov/pmc/articles/PMC5072826/

WHO (2013). Childhood Stunting: Context, Causes and Consequences WHO Conceptual framework. Maternal and Chind Nutrition, 9(11): 27-45. https://onlinelibrary.wiley.com/doi/epdf/10.1111/mcn.12075

Yisak H, Gobena T, Mesfin F (2015). Prevalence and Risk Factors for Under Nutrition among Children Under Five at Haramaya District, Eastern Ethiopia. BioMed Central Pediatrict, 15(212). http://dx.doi.org/10.1186/s12887-015-0535-0. 